\title{
THE CONTRIBUTION OF MARINE GEOLOGY TO THE SOCIO-ECONOMIC DEVELOPMENT OF GREECE: MARINE RESOURCES, INFRASTRUCTURE, ENVIRONMENT SUSTAINABILITY, CULTURAL HERITAGE
}

\section{A BRIEF ACCOUNT OF THE 30 YEARS CONTRIBUTION OF THE LABORATORY OF MARINE GEOLOGY AND PHYSICAL OCEANOGRAPHY}

\author{
Ferentinos G. \\ University of Patras, Department of Geology, Laboratory of Marine Geology and Physical Oceanography, \\ 26500 Patras, Greece, gferen@upatras.gr
}

\section{Introduction}

Marine geology is one of the core disciplines of Geology dealing with the geology of the oceans. In its broadest sense it includes the following major sub-disciplines:

(i) Marine geophysics and Tectonics,

(ii) Marine stratigraphy and Palaeo-oceanography,

(iii) Marine geochemistry and

(iv) Sedimentology.

Advances made from research in the above mentioned sub-discipline fields in the $2^{\text {nd }}$ half of the $20^{\text {th }}$ century lead to a new view of the earth's dynamics such as: Seafloor Spreading and Plate Tectonics, Tectonic History of the Oceans, Sea-Level History, Palaeo-oceanographic and Palaeoclimatologiec Changes.

Modern societal needs demand the extension of marine geology to new frontiers which would deal with the impact of human activity on the seas as well as with the impact of natural processes (hazards) on human activities.

The aims of this paper are to (i) outline human activity that occur in the oceans, (ii) discuss the impact of this activity on the environment as well as the impact of the marine geological processes on the activity and (iii) to present examples of how marine geology can contribute to the socio-economic development in Greece, through its involvement in the exploration, exploitation, development, management and risk assessment studies of the resources, infrastructure, environment sustainability and protection of the cultural heritage in the Greek Archipelago.

\section{The beginning of marine geology in Greece}

The "Challenger" expedition (1872-1876) marked the beginning of the systematic study of the oceans and consequently the beginning of "marine geology" as a discipline of geology, all around the world. 
During this expedition the first deep soundings and sediment samples on a global scale were taken. The sounding data collected, resulted in the first published bathymetric chart of the Atlantic Ocean whilst the sediment samples collected, contributed to the recognition of the major types of ocean sediments and their distribution patterns.

At about the same time the discovery of telegraphy and the prospect of extending the new means of rapid communication between continents (i.e. Europe-America) by laying submarine telegraph cables, gave the incentive to industry to become involved in the study of the seabed morphology and sediments or rocks lying on it, to ensure safe laying of the cables. This was the first application of marine geology on industrial activity in the seas.

Here in Greece the first surveys directly or indirectly related to the study of geological phenomena occurring under the sea and affecting human activities were carried out by: (i) A. Miaoulis (an officer in the Greek Admiralty) in Amvrakikos Gulf, in 1866, (ii) the Bell telegraph and telephone Company in the Gulf of Corinth between 1897 and 1950 and (iii) Prof. G. Georgalas and N. Liatsikas, both geologists, in the Greek Geological Survey in the Gulf of Santorini in 1930.

The first survey was carried out in Amfilochia (Karvasara) Bay to try to locate a possible underwater volcano, based on information that during the 1847 and 1865 earthquakes, sulfur emanated from the seafloor causing the death of shells and fish.

The second set of surveys was carried out in the Gulf of Corinth for the purpose of laying and repairing submarine telegraph/telephone cables damaged by the occurrence of submarine landslides. The surveys revealed the high frequency occurrence of landslides, on average 2 landslides every 3 years. The third survey was carried out in the Santorini Gulf after the 1925-26 and 1928 eruption of the Santorini Volcano, to examine the occurrence of changes in the morphology of the seafloor caused by the eruptions and to study the composition of the gas and water emanating from the seafloor.

\section{Human activity in the seas}

Current human activity in the seas are related to: (i) exploitation/exploration of non-living and living resources, (ii) coastal and offshore engineering structures and coastal protection, (iii) wave and wind power driven production, (iv) submarine telecommunication and power connections and (v) marine pollution and waste management (Table 1).

\section{Table 1.}

\begin{tabular}{|l|l|l|l|l|}
\hline \multicolumn{5}{|c|}{ MAN'S ACTIVITIES IN THE OCEANS AND INLAND WATERS } \\
\hline $\begin{array}{l}\text { Exploitation/ } \\
\text { exploration of } \\
\text { non-living \& } \\
\text { living resources }\end{array}$ & $\begin{array}{l}\text { Harbour } \\
\text { construction \& } \\
\text { coastal } \\
\text { management }\end{array}$ & $\begin{array}{l}\text { Submarine } \\
\text { cable connections }\end{array}$ & $\begin{array}{l}\text { Marine } \\
\text { pollution and } \\
\text { waste manage- } \\
\text { ment }\end{array}$ & $\begin{array}{l}\text { Human activity } \\
\text { on land which } \\
\text { affects the marine } \\
\text { environment }\end{array}$ \\
\hline $\begin{array}{l}\text { - Oil \& Gas } \\
\text { - Non-Petroleum } \\
\text { Minerals } \\
\text { - Benthic Fish- } \\
\text { eries }\end{array}$ & $\begin{array}{l}\text { Selection of site } \\
\text { - Dredged spoil } \\
\text { - Bquach protection } \\
\text { - Beach nourish- } \\
\text { ment }\end{array}$ & $\begin{array}{l}\text { - Telecommunic- } \\
\text { ation links } \\
\text { - Power links }\end{array}$ & $\begin{array}{l}\text { Waste Material } \\
\text { - Dredged spoil } \\
\text { - Sewage sludge } \\
\text { - Industrial by- } \\
\text { products }\end{array}$ & $\begin{array}{l}\text { - Dams \& Reser- } \\
\text { voirs } \\
\text { Rivers } \\
\text { Deforestration/ } \\
\text { Farming }\end{array}$ \\
\hline
\end{tabular}


Table 2.

\begin{tabular}{|c|c|c|c|}
\hline \multicolumn{4}{|c|}{$\begin{array}{l}\text { ENVIRONMENTAL IMPACTS OF MAN'S ACTIVITIES IN THE OCEAN } \\
\text { RELATED TO GEOLOGICAL PROCESSES }\end{array}$} \\
\hline $\begin{array}{l}\text { Type of } \\
\text { activity }\end{array}$ & Impact & Cause & $\begin{array}{l}\text { Information required for the } \\
\text { protection of the marine } \\
\text { environment }\end{array}$ \\
\hline $\begin{array}{l}\text { Harbour } \\
\text { construction }\end{array}$ & $\begin{array}{l}\text { Shoreline erosion and/or } \\
\text { accretion }\end{array}$ & Waves and Currents & $\begin{array}{l}\text { - Sediments texture } \\
\text { - Rates of erosion / accretion } \\
\text { - Waves \& Current regime }\end{array}$ \\
\hline $\begin{array}{l}\text { - Harbour \& } \\
\text { Channel main- } \\
\text { tenance } \\
\text { dredged spoil } \\
\text { - Sewage } \\
\text { sludge } \\
\text { - Industrial by- } \\
\text { products } \\
\text { - Marine } \\
\text { mining }\end{array}$ & $\begin{array}{l}\text { Changes in the physical, } \\
\text { chemical and biological } \\
\text { parameters of the partic- } \\
\text { ulate matter in the water } \\
\text { column and of the sedi- } \\
\text { ments on the seafloor }\end{array}$ & $\begin{array}{l}\text { Introduction of } \\
\text { - coarse and/or fine } \\
\text { material } \\
\text { - contaminants } \\
\text { 1. heavy metals } \\
\text { 2. organic com- } \\
\text { pounds } \\
\text { 3. radioactive } \\
\text { wastes }\end{array}$ & $\begin{array}{l}\text { - Hydraulic regime } \\
\text { - Particulate matter } \\
\text { 1. Grain size } \\
\text { 2. Composition } \\
\text { 3. Density } \\
\text { - Physical \& mechanical proper- } \\
\text { ties of the sediments on the } \\
\text { seafloor: } \\
\text { - Bedform geometry } \\
\text { - Man-made particles: } \\
\text { 1. Shape } \\
\text { 2. Grain size } \\
\text { 3. density } \\
\text { 4. composition }\end{array}$ \\
\hline Aquaculture & $\begin{array}{l}\text { Changes in the physical, } \\
\text { chemical and biological } \\
\text { parameters of the partic- } \\
\text { ulate matter in the water } \\
\text { column and of the sedi- } \\
\text { ments on the seafloor }\end{array}$ & $\begin{array}{l}\text { - Introduction in the } \\
\text { marine environment } \\
\text { of waste food and } \\
\text { faecal pellets } \\
\text { - Direct release of } \\
\text { nutrients }\end{array}$ & $\begin{array}{l}\text { - Hydraulic regime } \\
\text { - Particulate matter } \\
\text { 1. Grain size } \\
\text { 2. Composition } \\
\text { 3. Density } \\
\text { - Physical \& mechanical proper- } \\
\text { ties of the sediments on the } \\
\text { seafloor: } \\
\text { - Bedform geometry }\end{array}$ \\
\hline $\begin{array}{l}\text { Benthic } \\
\text { fisheries }\end{array}$ & $\begin{array}{l}\text { Changes in the physical, } \\
\text { chemical and biological } \\
\text { parameters of the sedi- } \\
\text { ments on the seafloor }\end{array}$ & $\begin{array}{l}\text { Trawling and } \\
\text { dredging equipment }\end{array}$ & $\begin{array}{l}\text { - Hydraulic regime } \\
\text { - Physical \& mechanical proper- } \\
\text { ties of the sediments on the } \\
\text { seafloor } \\
\text { - Sediment-Biota interaction }\end{array}$ \\
\hline $\begin{array}{l}\text { Deforestation \& } \\
\text { cultivation }\end{array}$ & $\begin{array}{l}\text { Changes in the physical, } \\
\text { chemical and biological } \\
\text { parameters of the partic- } \\
\text { ulate matter in the water } \\
\text { column and of the sedi- } \\
\text { ments on the seafloor }\end{array}$ & $\begin{array}{l}\text { Anthropogenically } \\
\text { mobilized soil }\end{array}$ & $\begin{array}{l}\text { - Hydraulic regime } \\
\text { - Particulate matter } \\
\text { 1. Grain size } \\
\text { 2. Composition } \\
\text { 3. Density } \\
\text { - Physical \& mechanical properties } \\
\text { of the sediments on the seafloor: }\end{array}$ \\
\hline
\end{tabular}


Table 2. Continued

\begin{tabular}{|c|c|c|c|}
\hline \multicolumn{4}{|c|}{$\begin{array}{l}\text { ENVIRONMENTAL IMPACTS OF MAN'S ACTIVITIES IN THE OCEAN } \\
\text { RELATED TO GEOLOGICAL PROCESSES }\end{array}$} \\
\hline $\begin{array}{l}\text { Type of } \\
\text { activity }\end{array}$ & Impact & Cause & $\begin{array}{l}\text { Information required for the } \\
\text { protection } \\
\text { of the marine } \\
\text { environment }\end{array}$ \\
\hline & & & $\begin{array}{l}\text { - Bedform geometry } \\
\text { - Sediment-Biota interaction }\end{array}$ \\
\hline $\begin{array}{l}\text { Dams and reser- } \\
\text { voirs } \\
\text { River diversion }\end{array}$ & $\begin{array}{l}\text { - Shoreline erosion } \\
\text { - Changes in the physi- } \\
\text { cal, chemical and bio- } \\
\text { logical parameters of } \\
\text { the particulate matter } \\
\text { in the water column } \\
\text { and of the sediments } \\
\text { on the seafloor }\end{array}$ & $\begin{array}{l}\text { Reduction of sedi- } \\
\text { ment supply }\end{array}$ & $\begin{array}{l}\text { - Texture of sediments } \\
\text { - Waves \& Current regime } \\
\text { - Physical \& mechanical proper- } \\
\text { ties of the sediments on the } \\
\text { seafloor: } \\
\text { - Bedform geometry } \\
\text { - Man-made particles: } \\
\text { 1.Shape } \\
\text { 2.Grain size } \\
\text { 3. density } \\
\text { - Sediment-Biota interaction }\end{array}$ \\
\hline
\end{tabular}

The above mentioned human activity has as impact on the marine environment (Table 2 ) like: (i) shoreline modification (erosion and/or accretion) and (ii) modification of the physical, chemical and biological parameters of the sea water and of the particulate matter in it and of the sediments on the sea floor. These changes in turn affect the balance of the biogeochemical processes which operates in the marine environment resulting in its degradation. There is also human activity on land, such as dam and reservoir construction, river diversion, farming and deforestation which affect the mariner environment.

To avoid, mitigate and/or take remedial measures on the impacts imposed to the marine environment by human activity, knowledge of the causal factors is needed as well as how these factors operate (Table 2). Furthermore a detailed knowledge of the physical, chemical and biological parameters which occur in the marine environment is needed (Table 2).

As human activity in the marine environment increases, natural hazards become more frequent and environmental risks more common place (Table 3).

Marine geology, based on the scientific issues that it covers is considered the relevant science to resolve, evaluate, remediate and mitigate man's impact on the marine environment and the natural processes (hazards) impact on man's activity.

\section{Case studies}

The case studies presented below are based on a 30 year involvement and experience be the Laboratory in natural hazard risk assessment studies, environment assessment studies, vulnerability studies, infrastructure site selection studies related to harbour, pipeline and cable route engineering works, harbour and channel dredging, monitoring of environmental parameters in coastal waters and protection and management of submarine heritage. 
Table 3.

\begin{tabular}{|c|c|c|c|}
\hline \multicolumn{4}{|c|}{$\begin{array}{l}\text { ENVIRONMENTAL HAZARDS* TO MAN'S ACTIVITIES IN THE OCEAN RELATED TO } \\
\text { GEOLOGICAL PROCESSES }\end{array}$} \\
\hline $\begin{array}{l}\text { Type of } \\
\text { activity }\end{array}$ & Hazard & Cause & $\begin{array}{l}\text { Information required for the } \\
\text { safe construction } \\
\text { and operation }\end{array}$ \\
\hline $\begin{array}{l}\text { - Gas \& Oil } \\
\text { platforms } \\
\text { - Pipilines/ Out- } \\
\text { falls } \\
\text { - Submarine ca- } \\
\text { bles } \\
\text { - Harbours }\end{array}$ & $\begin{array}{l}\text { Gravitative Mass } \\
\text { Movements: } \\
\text { - Slides } \\
\text { - Slumps } \\
\text { - Sediment flows } \\
\text { - Turbidity currents }\end{array}$ & $\begin{array}{l}\text { Static Loading: } \\
\text { - Insufficient sedi- } \\
\text { ment bearing ca- } \\
\text { pacity } \\
\text { Cyclic Loading: } \\
\text { - Earthquakes } \\
\text { - Storms \& storm } \\
\text { surges } \\
\text { - Tsunamis } \\
\text { - Structure vibration }\end{array}$ & $\begin{array}{l}\text { - Physical \& mechanical proper- } \\
\text { ties of sediments } \\
\text { - Gas in sediments }\end{array}$ \\
\hline $\begin{array}{l}\text { - Gas \& Oil } \\
\text { platforms } \\
\text { - Harbours } \\
\text { - Pipilines/ Out- } \\
\text { falls } \\
\text { - Submarine ca- } \\
\text { bles }\end{array}$ & Erosion \& Deposition & $\begin{array}{l}\text { - Waves \& Currents } \\
\text { - Storm \& Storm } \\
\text { surges }\end{array}$ & $\begin{array}{l}\text { - Texture and density of sedi- } \\
\text { ments } \\
\text { - Bedform geometry } \\
\text { - Wave and current regime }\end{array}$ \\
\hline $\begin{array}{l}\text { Emplacement } \\
\text { of nuclear } \\
\text { wastes deep in } \\
\text { the seafloor for } \\
\text { storage }\end{array}$ & $\begin{array}{l}\text { Transport of radionu- } \\
\text { clides to the seafloor }\end{array}$ & $\begin{array}{l}\text { - Seafloor erosion } \\
\text { - Thermal \& fluid- } \\
\text { mechanical re- } \\
\text { sponses of } \\
\text { sediment }\end{array}$ & $\begin{array}{l}\text { Physical \& mechanical proper- } \\
\text { ties of sediments } \\
\text { - fine grained clays } \\
\text { - low permeability } \\
\text { - low shear strength } \\
\text { Depositional environment } \\
\text { (pelagic) and absence of any } \\
\text { erosive episodes by currents or } \\
\text { mass wasting }\end{array}$ \\
\hline
\end{tabular}

* are defined as the highest values of forces resulting from geological, oceanographical and meteorological phenomena in an area

\subsection{A natural hazard risk assessment study in the Corinth Gulf}

The Gulf of Corinth is an active half-graben characterized by intense seismic activity. Marine geological surveys were carried out to evaluate: (i) the maximum probable expected offshore earthquake magnitude, (ii) the potential sources of submarine landslides and (iii) the potential tsunami hazard imposed by active offshore faults and submarine landslides.

The surveys showed that: 
(i) the fault trace length of the offshore faults is between 5 and $15 \mathrm{~km}$. This suggests that the expected maximum earthquake magnitude would be $6.5 \mathrm{R}$ based on regression equations correlating to fault trace length and seismic moment magnitude. However, it should be noted that the maximum recorded earthquake magnitude in the Gulf on Feb, $24^{\text {th }} 1981$ was $6.7 \mathrm{R}$.

(ii) the potential maximum seismic fault surface displacement is estimated to be about $1 \mathrm{~m}$ and therefore the potential maximum wave height in the Gulf above the source would be expected to be approximately the same as the co-seismic vertical displacement.

(iii) the potential maximum tsunami wave height, due to a submarine landslide in the Gulf would be $4.04 \mathrm{~m}$ above the source, based on the existing knowledge regarding landslide source area, landslide size, slope dip and traveling distance.

\subsection{The Navarino naval battle site, Greece: an integrated remote-sensing survey and a rational management approach}

Navarino Bay is a natural sheltered anchorage in the southern Ionian Sea, located near the town of Pylos. Navarino Bay has been a haven for ships for thousands of years due to its central location in the Mediterranean Sea. During the Greek war of independence from the Ottoman Empire, one of the most significant battles in European history fought there in 1827. At present oil tankers and large cargo vessels en route from oil-rich Middle East countries to Europe usually stop at Navarino Bay.

The $3.5 \mathrm{KHz}$ seismic and side scan sonar survey in the Bay has shown that:

(i) the floor of Navarino Bay is covered by soft mud more than $25 \mathrm{~m}$ in thickness and that the seafloor is scoured by the anchors of the moored tankers. The scour marks are up to $2 \mathrm{~m}$ wide, up to $300 \mathrm{~m}$ long and up to $2 \mathrm{~m}$ deep.

(ii) shipwreck remains of the battle lies on the seafloor and possible few shipwrecks are buried under the seabed.

(iii) shipwreck remains are under threat from the heavy anchors of tankers which sink into the seabed and when dragged dig furrows in the seabed, thus disintegrating the shipwrecks.

(iv) the wreckship remains can be protected from further destruction by the construction of permanent offshore anchoring systems away from the shipwreck remains.

\subsection{Geological and man-made hazards for laying submarine cable in the Aegean and Ionian Seas}

Greece is surrounded by more than one hundred islands scattered throughout the Aegean and Ionian archipelagos. The boom in business and tourism over the last three decades has resulted in the need of laying many submarine power and telephone cables between the Greek mainland and the islands. For the safe laying of the cables and the avoidance of any after laying cable failures, the safest seafloor route must be selected. The route must be as much as possible free from any potential geological and man-made hazards.

The geological and man-made hazards which pose damage to the cables are: (a) active faults and earthquakes, (b) pock-marks and gas charged sediments, (c) salt doming, (d) tsunami, (e) submarine landslides, (f) erosional features on the seabed (canyons, channels), (g) anomalous relief, (h) sediment erosion, transport and deposition and (i) human activity such as fishing, dredging, anchoring and wrecks on the seafloor.

The experience gained by the Laboratory through its involvement in feasibility studies for submarine cable links between the Greek mainland and the islands, suggests that it is essential for a ma- 
rine geological survey to be carried out by the governmental organization or the private industry interested in the submarine cable link for the selection of the safest cable route, the feasibility of the cable burial, the degree of difficulty involved in the burial of the cable and the selection of the most efficient burial method. The above studies must be done before the order is given to the cable manufacturer and the cable laying company to ensure that no mistakes are made and also to keep the cost at a minimum.

\section{Acknowledgments}

I would like to mention that in all this 30 year involvement of the Laboratory in marine geology, the contribution of all the post-graduate students of the Laboratory, who spent days and nights in the sea and some of whom are now scientific personnel in the Laboratory or somewhere else, cannot be underestimated. Their hard work and dedication in the scientific effort of the Laboratory was indeed a very important factor in the success of the Laboratory, which could not have achieved without them.

I refer in particular to:

1. G. Papatheodorou (Associate Professor, Department of Geology, Patras University).

2. N. Kastanos (Secondary School Teacher).

3. P. Achelleopoulos (Secondary School Teacher).

4. I. Zacharias (Assistant Professor, Department of Environment, Ioannina University).

5. G. Gkionis (Marine Geologist, Consultant).

6. M. Geraga (Lecturer, Department of Geology, Patras University).

7. T. Hasiotis (Lecturer, Department of Marine Science, Aegean University).

8. A. Stefatos (Senior Marine Geophysist, Rock Resources, Norway).

9. A. Chalari (Underwater Archaeology, Laboratory of Marine Geology).

10. D. Christodoulou (Research Associate, Laboratory of Marine Geology).

11. M. Iatrou (Post-graduate student).

12. I. Fakiris (Post-graduate student).

13. M. Prevenios (Post-graduate student). 